ISSN : $2406-7415$

e-ISSN : 2655 - 9919

JURNAL AKUNTANSI DAN BISNIS KRISNADWIPAYANA

DOI: http://dx.doi.org/10.35137/jabk.v7i3.447

Vol. 7 No. 3 (September - Desember) 2020

\title{
PENGELOLAAN ASET TETAP BERDASARKAN METODE REVALUASI TERKAIT DENGAN PERENCANAAN PAJAK PENGHASILAN (STUDI PADA RUMAH SAKIT YADIKA PONDOK BAMBU)
}

\author{
Try Masroyany ${ }^{1}$ \\ ${ }^{1}$ Fakultas Ekonomi Universitas Krisnadwipayana \\ Jalan Unkris Jatiwaringin Jakarta Timur \\ Email: trymasroyani94@gmail.com \\ Hayuningtyas Pramesti Dewi ${ }^{2}$ \\ ${ }^{2}$ Fakultas Ekonomi Universitas Krisnadwipayana \\ Jalan Unkris Jatiwaringin Jakarta Timur \\ Email: ethniz@gmail.com
}

\begin{abstract}
This study aims to provide a viewof the fixed assets measurement using the revaluation method for the fairness of financial statements and their impact on savings on entity's taxes. The research was conducted in descriptive qualitative using secondary data from the research namely Rumah Sakit Yadika Pondok Bambu in 2018. The result of the study show that using the revaluation method in addition to measuring and presenting fixed assets can reflects the real conditions of the assets and can also save income tax for entity.

Keyword: Fixed Assets, Revaluation Method, Tax.
\end{abstract}

\section{PENDAHULUAN}

Revaluasi aset tetap dilakukan untuk memberikan kewajaran dari nilai suatu aset karena aset dinilai berdasarkan nilai wajar yang sedang berlaku di pasar pada saat dilakukan penilaian. Adapun revaluasi dilakukan pada aset-aset yang umur ekonomisnya panjang sehingga nilai aset tersebut dapat mencerminkan kondisi yang sesungguhnya. Adapun penilaian revaluasi pada aset tetap dapat merubah nilai beban penyusutan aset tetap tersebut sehingga dapat mempengaruhi nilai laba entitas dan juga akan mempengaruhi perhitungan pajak entitas karena perhitungan pajak yang harus dibayar entitas dasarnya adalah laba.

Membayar dan melaporkan pajak adalah salah satu kewajiban entitas kepada negara. Meskipun demikian entitas memperlakukan kewajiban ini sebagai biaya yang mengurangi laba. Karena itu entitas selalu berupaya untuk mengefisienkan biaya pajak ini agar laba tidak banyak tergerus. Salah satu cara entitas untuk mengefisienkan biaya pajak adalah dengan melakukan perencanaan pajak (tax planning) yang mana merupakan perencanaan pemenuhan kewajiban perpajakan secara benar, lengkap dan tepat waktu tanpa menghindari kewajiban pajak dan melanggar undang-undang perpajakan.

Salah satu cara melakukan perencanaan pajak adalah yang terkait dengan Aset Tetap. Perencanaan pajak dapat dilakukan dengan menghitung penyusutan aset tetap entitas dengan metode tertentu yang telah diatur oleh undang-undang perpajakan dan revaluasi aset tetap. Revaluasi atau penilaian kembali aset tetap untuk tujuan perpajakan diatur oleh Peraturan Menteri Keuangan (PMK) Nomor

61

Copyright (c) 2020 Hayuningtyas Pramesti Dewi, SE., Ak., M.Ak., CA, Try Masroyany

This work is licensed under a Creative Commons Attribution-NonCommercial-ShareAlike 4.0 International License. 
ISSN : $2406-7415$

e-ISSN : 2655 - 9919

JURNAL AKUNTANSI DAN BISNIS KRISNADWIPAYANA

DOI: http://dx.doi.org/10.35137/jabk.v7i3.447

191/PMK.010/2015. PMK tersebut memuat jenis-jenis aset tetap yang dapat direvaluasi, dasar penentuan revaluasi aset tetap dan perlakuan apabila terdapat selisih lebih dari revaluasi aset tetap.

Objek dari penelitian ini adalah Rumah Sakit Yadika Pondok Bambu yang merupakan sebuah entitas yang bergerak di bidang kesehatan. Dalam menjalankan aktivitasnya, Rumah Sakit Yadika Pondok Bambu menggunakan berbagai aset tetap, yang terdiri dari alat, mesin-mesin kesehatan, kendaraan, peralatan kantor, instalasi jaringan listrik, telepon dan internet. Masa manfaat sebagian aset tetap akan berakhir namun kondisi aset tetap tersebut masih layak digunakan dan memiliki nilai jual. Dengan demikian perlu dilakukan revaluasi atas nilai aset tetap tersebut agar nilai dan kemampuan aset tetap dapat tercermin secara wajar. Adapun setelah penilaian kembali pasti akan mempengaruhi besaran pajak entitas. Tujuan dari penelitian ini adalah untuk memberikan pandangan perhitungan pengukuran aset tetap jika menggunakan metode revaluasi dan juga terkait dengan perencanaan untuk penghematan pajaknya. Adapun penelitian yang sejalan pernah dilakukan oleh Wijaya (2007) dengan hasil penelitian menunjukkan bahwa revaluasi aktiva tetap untuk tujuan perpajakan dapat meningkatkan laba bersih, aset, dan ekuitas, revaluasi aktiva juga dapat memberikan manfaat berupa berkurangnya pajak penghasilan untuk tahun setelah revaluasi serta manfaat ekonomi lainnya, yaitu performa keuangan yang meningkat.
Vol. 7 No. 3 (September - Desember) 2020

\section{LANDASAN TEORI}

\section{Aset Tetap}

Menurut Kartika Hadi (2018) aset tetap adalah aset berwujud yang dimiliki untuk digunakan dalam produksi atau penyediaan barang atau jasa untuk disewakan kepada pihak lain atau untuk tujuan administratif dan diharapkan dapat digunakan selama lebih dari satu periode. Rudianto (2017) mendefinisikan aset tetap adalah barang berwujud milik entitas yang sifatnya relatif permanen dan digunakan dalam kegiatan normal entitas, bukan untuk diperjual belikan. Sedangkan menurut Hery (2017) aset tetap adalah aset yang secara fisik dapat dilihat keberadaannya dan sifatnya relatif permanen serta memiliki masa kegunaan (useful life) yang panjang. Aset tetap dapat diperoleh dengan berbagai macam cara, yaitu dengan pembelian tunai, pembelian secara mengangsur atau dengan pertukaran.

Pengukuran awal Aset Tetap.

Menurut PSAK 16 tentang Aset Tetap, aset yang memenuhi kualifikasi diakui sebagai Aset Tetap pada awalnya harus diukur sebesar harga perolehannya, yang mana harga perolehan merupakan jumlah keseluruhan biaya yang dikeluarkan oleh entitas bisnis untuk memperoleh aset tetap tersebut dari harga beli ditambah pengeluaran yang timbul sampai aset tersebut siap digunakan. Selanjutnya setelah pengukuran awal entitas dapat memilih model kebijakan pengukuran terhadap seluruh asetnya dalam kelompok yang sama. Menurut Lam (2017) model kebijakan akuntansi untuk seluruh aset tetap adalah: 1) Model Biaya, yaitu kebijakan pengukuran aset tetap sebesar biaya dikurangi akumulasi penyusutan dan dikurangi akumulai kerugian penurunan nilai 
ISSN : $2406-7415$

e-ISSN : 2655 - 9919

JURNAL AKUNTANSI DAN BISNIS KRISNADWIPAYANA

DOI: http://dx.doi.org/10.35137/jabk.v7i3.447

jika ada. 2) Model Revaluasi. Pengukuran aset tetap dengan model revaluasi yaitu dengan cara jumlah yang direvaluasi (nilai wajar aset pada tanggal revaluasi) dikurangi akumulasi penyusutan dan dikurangi akumulasi kerugian penurunan nilai.

\section{Penyusutan Aset Tetap}

Berdasarkan PSAK No 16 tentang Aset Tetap, penyusutan aset dipilih berdasarkan ekspektasi pola konsumsi manfaat ekonomik masa depan dari aset dan diterapkan secara konsisten dari periode ke periode kecuali ada perubahan dalam ekspektasi pola konsumsi manfaat ekonomik masa depan dari aset. Metode penyusutan yang digunakan untuk mengalokasi jumlah yang disusutkan secara sistematis suatu aset selama umur manfaatnya terdiri dari:

1. Metode garis lurus (straight line method), menghasilkan pembebanan yang tetap selama umur masa manfaat aset tetap

Besarnya beban penyusutan dapat dihitung denga rumus sebagai berikut:

Beban Penyusutan = $\underline{\text { Biaya Perolehan }- \text { Nilai Residu }}$

Estimasi Umur Manfaat

Tarif Penyusutan $=$ $\underline{100 \%}$ Umur Manfaat

2. Metode saldo menurun (diminishing balance method), menghasilkan pembebanan yang menurun selama umur manfaat aset tetap. Untuk menentukan presentase penyusutan dalam periode ini dengan mengalikan dua presentase tarif penyusutan garis lurus dengan rumus Baridwan, (2018).

Penyusutan $=2 \times(100 \%$ : Umur Manfaat $)$

3. Metode jumlah unit (sum of the unit method), menghasilkan pembebanan berdasarkan pada penggunaan atau output yang diharapkan dari suatu aset tetap. Dasar teori yang dipakai dalam metode ini adalah bahwa suatu aset itu dimiliki untuk menghasilkan produk,
Vol. 7 No. 3 (September - Desember) 2020 sehingga penyusutan juga didasarkan pada jumlah produk yang dihasilkan. Rumus metode ini menurut Baridwan (2018).

Penyusutan $=$ Harga Perolehan - Nilai sisa Taksiran Jumlah Produksi

Penyusutan Aset Tetap berdasarkan peraturan perpajakan.

Berdasarkan Undang - Undang Perpajakan menurut ketentuan perpajakan (pasal 11 Undang - Undang PPh No.36 tahun 2008) metode penyusutan adalah sebagai berikut.

1. Metode garis lurus (straight line method), atau metode saldo menurun (declining balance method) untuk aset tetap berwujud bukan bangunan.

2. Metode garis lurus untuk aset tetap berwujud berupa bangunan.

Penentuan kelompok dan tarif penyusutan aset berwujud didasarkan pada Pasal 11 Undang - Undang No.36 Tahun 2008 tentang Pajak Penghasilan.

Tabel 1. Penggolongan aset tetap menurut ketentuan pajak

\begin{tabular}{|c|c|c|c|}
\hline $\begin{array}{l}\text { Kelompok } \\
\text { Harta } \\
\text { Berwujud }\end{array}$ & $\begin{array}{l}\text { Masa } \\
\text { Manfaat }\end{array}$ & $\begin{array}{l}\text { Tarif } \\
\text { Penyusutan } \\
\text { berdasarkan } \\
\text { Metode } \\
\text { Garis Lurus }\end{array}$ & $\begin{array}{l}\text { Tarif } \\
\text { Penyusutan } \\
\text { berdasarkan } \\
\text { Metode } \\
\text { Saldo } \\
\text { Menurun }\end{array}$ \\
\hline $\begin{array}{l}\text { Bukan } \\
\text { bangunan } \\
\text { Kelompok } \\
1 \\
\text { Kelompok } \\
2 \\
\text { Kelompok } \\
3 \\
\text { Kelompok } \\
4\end{array}$ & $\begin{array}{l}4 \text { Tahun } \\
8 \text { Tahun } \\
16 \text { Tahun } \\
20 \text { Tahun }\end{array}$ & $\begin{array}{l}25 \% \\
12,50 \% \\
6,25 \% \\
5 \%\end{array}$ & $\begin{array}{l}50 \% \\
25 \% \\
12,5 \% \\
10 \%\end{array}$ \\
\hline $\begin{array}{l}\text { Bangunan } \\
\text { Permanen } \\
\text { Tidak } \\
\text { Permanen }\end{array}$ & $\begin{array}{l}20 \text { Tahun } \\
10 \text { Tahun }\end{array}$ & $\begin{array}{l}5 \% \\
10 \%\end{array}$ & - \\
\hline
\end{tabular}

Sumber: Waluyo (2018:135) 
ISSN : $2406-7415$

e-ISSN : 2655 - 9919

JURNAL AKUNTANSI DAN BISNIS KRISNADWIPAYANA

DOI: http://dx.doi.org/10.35137/jabk.v7i3.447

\section{Revaluasi}

Revaluasi adalah penilaian kembali aset tetap entitas yang mana aset tetap memiliki umur ekonomis yang panjang sehingga memerlukan penilaian kembali sesuai dengan nilai yang sedang berlaku di pasar saat penilaian dilakukan untuk keperluan pelaporan keuangan. Menurut PSAK 16 tentang aset tetap, entitas dapat memilih salah satu dari dua metode penilaian aset tetap yaitu model biaya atau model revaluasi. Apabila entitas memilih metode revaluasi maka entitas harus melaksanakannya secara konsisten.

Revaluasi aset tetap dilakukan dalam kelompok yang sama. Revaluasi dilakukan dengan cara menselisihkan antara nilai tercatat aset tetap dengan nilai wajarnya, selisih tersebut akan dicatat sebagai laba/rugi revaluasi yang dilaporkan dalam laba rugi komprehensif sebagai bagian dari ekuitas. Apabila sebelum revaluasi terjadi penurunan nilai (impairment) aset maka penurunan nilai tersebut akan mengurangi laba revaluasi jika ada laba revaluasi, jika tidak ada laba revaluasi maka penurunan nilai tersebut akan mengurangi saldo laba.

Pajak atas revaluasi menurut PSAK 16 dipertanggungjawabkan mengikuti ketentuan dalam PSAK 46 tentang pajak penghasilan. Atas selisih revaluasi tidak diakui dalam laba rugi tahun berjalan tetapi diakui dalam laba komprehensif, maka konsekuensi pajaknya akan dimasukkan dalam komponen laba komprehensif. Jika pajak atas revaluasi ini tidak dikenakan menurut peraturan perpajakan maka konsekuensi pajaknya akan diakui sebagai aset atau liabiltas pajak tangguhan. Sebagai contoh atas keuntungan revaluasi tanah akan diakui debit beban pajak tangguhan atas surplus revaluasi dan kredit liabilitas pajak tangguhan.
Vol. 7 No. 3 (September - Desember) 2020

Tarif Revaluasi Aset khusus tahun 2015 dan 2016 itu sebagai berikut:

a 3\% (tiga persen), bagi Wajib Pajak yang telah memperoleh penetapan penilaian kembali aktiva tetap oleh kantor jasa penilai publik atau ahli penilai, dan melunasi Pajak Penghasilan sampai dengan tanggal 31 Desember 2015

b 4\% (empat persen), bagi Wajib Pajak yang telah memperoleh penetapan penilaian kembali aktiva tetap oleh kantor jasa penilai publik atau ahli penilai, dan melunasi Pajak Penghasilan dimaksud dalam jangka waktu sejak tanggal 1 Januari 2016 sampai dengan tanggal 30 Juni 2016

c $6 \%$ (enam persen), bagi Wajib Pajak yang telah memperoleh penetapan penilaian kembali aktiva tetap oleh kantor jasa penilai publik atau ahli penilai, dan melunasi Pajak Penghasilan dimaksud dalam jangka waktu sejak tanggal 1 Juli 2016 sampai dengan tanggal 31 Desember 2016

\section{Perencanaan Pajak}

Perencanaan pajak merupakan salah satu bentuk dari fungsi manajemen pajak dalam upaya melakukan penghematan pajak secara legal. Menurut Suandy (2018) Perencanaan pajak adalah langkah awal dari manajemen pajak. Sedangkan menurut Ompusunggu (2017) Tax Planning adalah suatu kapasitas wajib pajak untuk mengatur aktivitas keuangan yang dapat meminimalkan pembayaran pajak. Manfaat perencanaan pajak adalah dapat menghemat pengeluaran kas, mengatur aliran kas entitas karena dengan perencanaan pajak dapat diestimasikan kebutuhan kas yang akan digunakan dalam pembayaran pajak beserta 
ISSN : $2406-7415$

e-ISSN : 2655 - 9919

JURNAL AKUNTANSI DAN BISNIS KRISNADWIPAYANA

DOI: http://dx.doi.org/10.35137/jabk.v7i3.447

kapan waktunya sehingga dapat dianggarkan terlebih dahulu.

\section{METODE PENELITIAN}

Jenis penelitian adalah kualitatif deskriptif berupa analisa perencanaan pajak dari aktivitas revaluasi aset tetap di RS Yadika Pondok Bambu tahun 2018. Data sekunder berupa catatan-catatan pembukuan yang dilakukan oleh RS Yadika Pondok Bambu diperoleh dengan cara wawancara, observasi dan dokumentasi. Data dianalisis dengan menghitung simulasi pengukuran aset tetap objek penelitian dengan metode revaluasi dan menghitung perencanaan pajaknya terkait dengan revaluasi tersebut.

\section{HASIL PENELITIAN DAN PEMBAHASAN}

Kebijakan pengukuran aset tetap di RS Yadika Pondok Bambu menggunakan metode biaya, yaitu sebesar harga perolehan dikurangi akumulasi penyusutan. Selama ini RS Yadika Pondok Bambu belum pernah melakukan revaluasi aset tetapnya meski aset tetap tersebut memiliki umur ekonomis panjang dan masa manfaatnya hampir habis namun aset tetap masih dapat digunakan. Untuk pembebanan penyusutan digunakan metode saldo menurun. Berikut ini adalah jenis, masa manfaat dan tarif penyusutan aset tetap RS Yadika Pondok Bambu.

Tabel 2. Jenis, masa manfaat, tarif penyusutan RS Yadika Pondok Bambu

\begin{tabular}{|c|c|c|c|}
\hline No. & $\begin{array}{c}\text { Jenis Aset } \\
\text { Tetap }\end{array}$ & $\begin{array}{c}\text { Masa } \\
\text { Manfaat }\end{array}$ & $\begin{array}{c}\text { Tarif } \\
\text { Penyusutan }\end{array}$ \\
\hline 1 & $\begin{array}{l}\text { Alat dan } \\
\text { Mesin-mesin }\end{array}$ & & \\
\hline & Logam & 8 Tahun & $12.5 \%$ \\
\hline
\end{tabular}

Vol. 7 No. 3 (September - Desember) 2020

\begin{tabular}{|c|l|c|c|}
\hline & Non Logam & 4 Tahun & $25 \%$ \\
\hline 2 & Kendaraan & & \\
\hline & Mobil & 8 Tahun & $12.5 \%$ \\
\hline & \multicolumn{1}{|c|}{ Motor } & 4 Tahun & $25 \%$ \\
\hline 3 & $\begin{array}{l}\text { Instalasi } \\
\text { Jaringan } \\
\text { Telepon, } \\
\text { Listrik dan } \\
\end{array}$ & 8 Tahun & $12.5 \%$ \\
\hline 4 & Internet & \\
\hline & Peralatan & & \\
\hline & Logam & 8 Tahun & $12.5 \%$ \\
\hline
\end{tabular}

Sumber: RS Yadika Pondok Bambu (2020)

\section{Pembahasan}

Peraturan Menteri Keuangan Nomor 76/PMK03/2008 menjelaskan bahwa revaluasi aset tetap dilakukan untuk kewajaran nilai aset tetap. Revaluasi dilakukan berdasarkan nilai pasar atau nilai wajar suatu aset tetap yang harus ditetapkan oleh perusahaan jasa penilai atau ahli penilai yang memperoleh izin dari pemerintah. Apabila hasil revaluasi aset tetap tidak mencerminkan keadaaan yang sebenarnya, maka DJP dapat menetapkan kembali nilai revaluasi. Pendekatan yang digunakan dalam penilaian untuk memperoleh nilai wajar pada aset tetap tidak diatur secara spesifik. Sehingga nilai revaluasi tersebut akan memperbarui nilai aset tetap yang tercatat pada neraca fiskal dan dijadikan sebagai dasar penyusutan fiskal rumah sakit. Pengelompokkan aset tetap berdasarkan komoditi dapat diklasifikasikan atas dasar data statistik KBKI (Klasifikasi Baku Komoditas Indonesia) dari BPS Indonesia. Metode penentuan nilai wajar berdasarkan tata cara penilaian yang dilakukan oleh jasa penilai ada beberapa jenis, salah satunyaadalahmetode SPLA (Special Price Level Adjustment). Metode tersebut digunakan penilaian kembali aset tetap dengan cara mengalikan harga perolehan aset 
ISSN : $2406-7415$

e-ISSN : 2655 - 9919

JURNAL AKUNTANSI DAN BISNIS KRISNADWIPAYANA

DOI: http://dx.doi.org/10.35137/jabk.v7i3.447

tetap dengan angka indeks kelompok barang. Penentuan indeks pada metode ini dapat menggunakan tingkat inflasi untuk komoditas yang diperjual belikan secara luas. Angka indeks didapat dari Badan Pusat Statistik (BPS) Indonesia. Dalam penelitian menggunakan indeks harga Konsumen Menurut Kelompok Pengeluaran untuk mengetahui angka indeks terkait harga saat ini, dimana indeks tersebut merupakan indeks yang menunjukkan perubahan harga harga aset tetap pada saat tahun yang berjalan. Sesuai dengan karakteristik objek penelitian dari data diatas, penelitian ini mengambil 8 kelompok komoditas yang diperdagangkan, yaitu:

Tabel 3. Indeks harga komoditi perdagangan

\begin{tabular}{|c|l|c|}
\hline No & \multicolumn{1}{|c|}{ Kelompok Barang atau } & $\mathbf{2 0 1 8}$ \\
\hline 1 & $\begin{array}{l}\text { Barang-barang lainnya dari bahan } \\
\text { bukan logam }\end{array}$ & 131 \\
\hline 2 & $\begin{array}{l}\text { Barang-barang dari besi dan baja } \\
\text { dasar }\end{array}$ & 146 \\
\hline 3 & Alat pertukangan dari logam & 159 \\
\hline 4 & Barang-barang logam lainnya & 135 \\
\hline 5 & Alat-alat berat dan perlengkapannya & 147 \\
\hline 6 & Mesin pembangkit dan motor listrik & 132 \\
\hline 7 & Perlengkapan listrik lainnya & 132 \\
\hline 8 & $\begin{array}{l}\text { Bangunan dan instalasi listrik, gas, } \\
\text { air minum, dan komunikasi }\end{array}$ & 133 \\
\hline
\end{tabular}

Sumber: BPS (Badan Pusat Statistik) Indonesia

Indeks yang diperoleh dari BPS adalah indeks harga pada tahun 2018, misalnya saja apabila indeks harga kelompok alat pertukangan dari logam tahun 2018 adalah 159, artinya perubahan harga pada tahun 2018 kelompok perlengkapan, peralatan, dan pemeliharaan rutin rumah tangga adalah $159 \%$ jika dirupiahkan misal harga alat pertukangan dari logam adalah Rp 10.000, maka di tahun 2018 adalah Rp 15.900.
Vol. 7 No. 3 (September - Desember) 2020

Dari perhitungan sebelum dan sesudah revaluasi terdapat selisih revaluasi. Berikut ini adalah pengukuran aset tetap dengan metode revaluasi pada tahun 2018 dengan menggunakan angka indeks dari BPS Indonesia.

Tabel 4. Revaluasi Aset Tetap RS Yadika Pondok Bambu 2018

\begin{tabular}{|c|c|c|c|c|c|}
\hline No & Jenis Aset Tetap & $\begin{array}{c}\text { Nilai/ Harga } \\
\text { Perolehan }\end{array}$ & $\begin{array}{c}\text { Nilai Buku } \\
\text { Sebelum } \\
\text { Revaluasi }\end{array}$ & $\begin{array}{c}\text { Nilai Buku } \\
\text { Setelah } \\
\text { Revaluasi }\end{array}$ & Selisih \\
\hline 1 & $\begin{array}{l}\text { Alat dan Mesin - Mesin } \\
\text { Rumah Sakit }\end{array}$ & 3.638 .329 .433 & 466.188 .599 & 2.074 .099 .268 & 1.607.910.669 \\
\hline 2 & Kendaraan Rumah Sakit & 1.671 .857 .695 & 1.331 .326 .177 & 2.117 .099 .294 & 785.773 .117 \\
\hline 3 & $\begin{array}{l}\text { Instalasi Jaringan Listrik, } \\
\text { Telepon, dan Internet Rumah } \\
\text { Sakit }\end{array}$ & 213.533 .082 & 13.108 .636 & 91.283 .953 & 78.175 .317 \\
\hline 4 & Peralatan Rumah Sakit & 256.021 .818 & 79.322 .025 & 185.844 .461 & 106.522 .436 \\
\hline & \begin{tabular}{|c|} 
Total \\
\end{tabular} & 5.779 .742 .028 & 1.889 .945 .437 & 4.468 .326 .976 & 2.578 .381 .539 \\
\hline
\end{tabular}

Sumber: Data Diolah (2020)

Nilai aset tetap setelah revaluasi jika dibandingkan dengan nilai buku aset tetap sebelum revaluasi telah mengalami kenaikan sebesar Rp 2.578.381.539, jumlah tersebut terdiri dari selisih revaluasi aset tetap alat dan mesin - mesin rumah sakit $\mathrm{Rp}$ 1.607.910.669, kendaraan Rp 785.773.117, instalasi jaringan listrik, telepon dan internet sebesar Rp 78.175.317 dan selisih revaluasi peralatan rumah sakit sebesar Rp 106.522.436. Sehingga dari sini dapat disimpulkan bahwa total nilai buku aset tetap setelah revaluasi adalah sebesar $\mathrm{Rp}$ 4.468.326.976, total nilai buku aset tetap ini diperoleh dari nilai buku seluruh aset tetap sebelum revaluasi sebesar Rp 1.889.945.437 kemudian ditambah dengan selisih lebih atas revaluasi sebesar $\mathrm{Rp}$ 2.578.381.539.

Perhitungan beban penyusutan aset tetap setelah revaluasi akan disajikan dalam lima tahun berikutnya, dikarenakan berdasarkan peraturan perpajakan jangka waktu untuk bisa melakukan penilaian kembali adalah lima tahun berikutnya 
ISSN : $2406-7415$

e-ISSN : 2655 - 9919

JURNAL AKUNTANSI DAN BISNIS KRISNADWIPAYANA

DOI: http://dx.doi.org/10.35137/jabk.v7i3.447

Tabel 5. Beban penyusutan aset tetap setelah revaluasi

\begin{tabular}{|c|l|c|c|}
\hline No. & \multicolumn{1}{|c|}{ Jenis Aset Tetap } & $\begin{array}{c}\text { Nilai Buku } \\
\text { Setelah } \\
\text { Revaluasi }\end{array}$ & $\begin{array}{c}\text { Beban } \\
\text { Penyusutan } \\
\text { Tahun 2018 }\end{array}$ \\
\hline 1 & Alat dan Mesin - Mesin Rumah Sakit & 2.074 .099 .268 & 307.519 .302 \\
\hline 2 & Kendaraan Rumah Sakit & 2.117 .099 .294 & 346.781 .298 \\
\hline 3 & $\begin{array}{l}\text { Instalasi Jaringan Listrik, Telepon, dan } \\
\text { Internet Rumah Sakit }\end{array}$ & 91.283 .953 & 17.588 .807 \\
\hline 4 & Peralatan Rumah Sakit & 185.844 .461 & 34.327 .462 \\
\hline & Total & $\mathbf{4 . 4 6 8 . 3 2 6 . 9 7 6}$ & $\mathbf{7 0 6 . 2 1 6 . 8 6 9}$ \\
\hline
\end{tabular}

Sumber : Data Diolah Oleh Penulis (2020)

Berdasarkan tabel di atas dapat diketahui perhitungan beban penyusutan menggunakan metode saldo menurun, beban penyusutan setealah penyusutan disajikan per 31 Desember 2018 yaitu dengan total beban penyusutan sebesar Rp 706.216.869, perhitungan diperoleh dari akumulasi beban penyusutan kelompok aset alat dan mesinmesin rumah sakit sebesar Rp 307.519.302, kendaraan sebesar Rp 346.781.298, peralatan rumah sakit sebesar Rp 34.327.462, instalasi jaringan telepon, listriik dan internet $\mathrm{Rp}$ 17.588.807. Kemudian menghasilkan total nilai buku setelah revaluasi sebesar $\mathrm{Rp}$ 4.468.326.976.

Beban yang dikeluarkan oleh perusahaan pada laporan akan bertambah dikarenakan adanya beban penyusutan hasil penilaian kembali aset tetap, sedangkan nilai buku aset tetap yang terletak di laporan posisi keuangan akan berkurang karena adanya akumulasi penyusutan. Beban penyusutan setelah direvaluasi akan dicatat sebagai berikut:

(Dr) Beban Penyusutan

$$
\text { Rp 706.216.869 }
$$

(Cr) Akumulasi Penyusutan Rp 706.216.869

Dari hasil revaluasi aset tetap Rumah Sakit Yadika Pondok Bambu terdapat kenaikan beberapa kelompok aset tetap tertentu. Nilai buku untuk aset tetap yang telah habis masa manfaatnya dapat dilakukan penambahan umur ekonomis dan kebijakan
Vol. 7 No. 3 (September - Desember) 2020 atas penambahan umur ekonomis aset tetap tersebut yang dikembalikan kepada kebijakan perusahaan. Hal ini dapat dilihat berdasarkan PSAK 16 paragraf 57 yaitu penentuan umur masa aset tetap tergantung pada kebijakan perusahaan dimana manfaat ekonomis masa depan suatu aset dipakai oleh entitas terutama melalui penggunaannya.

Adanya selisih lebih revaluasi akibat penilaian kembali atas aset tetap yang dimiliki perusahaan, tentu akan merubah jumlah aset beserta modal pada laporan posisi keuangan perusahaan. Akibat dilakukannya penilaian kembali pada aset tetap akan timbul selisih lebih atau kurang yang dikarenakan perubahan nilai pada aset tersebut. Jika hasil menunjukkan selisih lebih, maka perusahaan berhak melakukan penilaian kembali pada aset tersebut. Dampak yang terjadi akibat adanya selisih lebih atau surplus revaluasi dapat dikategorikan sebagai penghasilan kena pajak dengan tarif $10 \%$ dan bersifat final sesuai dengan Peraturan Menteri Keuangan Nomor 79/PMK.03/2008 Pasal 5 atas selisih lebih penilaian kembali aset tetap perusahaan.

Tabel 6. Estimasi PPh final aset tetap setelah revaluasi (fiskal)

\begin{tabular}{|c|l|r|r|r|c|}
\hline No & \multicolumn{1}{|c|}{ Jenis Aset Tetap } & $\begin{array}{c}\text { Nilai Buku } \\
\text { Sebelum } \\
\text { Revaluasi }\end{array}$ & $\begin{array}{c}\text { Nilai Buku } \\
\text { Setelah } \\
\text { Revaluasi }\end{array}$ & Selisih & $\begin{array}{c}\text { PPh Final } \\
(\mathbf{1 0 \%})\end{array}$ \\
\hline 1 & Alat dan Mesin - Mesin Rumah Sakit & 466.188 .599 & 2.074 .099 .268 & 1.607 .910 .669 & 160.791 .067 \\
\hline 2 & Kendaraan Rumah Sakit & 1.331 .326 .177 & 2.117 .099 .294 & 785.773 .117 & 78.577 .312 \\
\hline 3 & $\begin{array}{l}\text { Instalasi Jaringan Listrik, Telepon, dan } \\
\text { Internet Rumah Sakit }\end{array}$ & 13.108 .636 & 91.283 .953 & 78.175 .317 & 7.817 .532 \\
\hline 4 & Peralatan Rumah Sakit & 79.322 .025 & 185.844 .461 & 106.522 .436 & 10.652 .244 \\
\hline & Total & $\mathbf{1 . 8 8 9 . 9 4 5 . 4 3 7}$ & $\mathbf{4 . 4 6 8 . 3 2 6 . 9 7 6}$ & $\mathbf{2 . 5 7 8 . 3 8 1 . 5 3 9}$ & $\mathbf{2 5 7 . 8 3 8 . 1 5 4}$ \\
\hline
\end{tabular}

Sumber : Data Diolah (2020)

Setelah direvaluasi fiskal, nilai buku aset tetap menjadi Rp 4.468.362.976 yaitu naik sebesar $\mathrm{Rp}$ 2.578.838.154 dari nilai buku sebelumnya. Nilai selisih lebih penilaian kembali yang tercatat didalam laporan posisi 
ISSN : $2406-7415$

e-ISSN : 2655 - 9919

JURNAL AKUNTANSI DAN BISNIS KRISNADWIPAYANA

DOI: http://dx.doi.org/10.35137/jabk.v7i3.447

keuangan bagian modal juga akan berkurang akibat adanya beban sebesar $10 \%$ ini, hal ini dikarenakan beban $\mathrm{PPh}$ final ini merupakan kewajiban perusahaan. Jadi total selisih lebih penilaian kembali yang sebelumnya $\mathrm{Rp}$ 2.578.838.154 dikurangi dengan PPh Final yang harus dibayarkan sebesar Rp 257.838.154. Sehingga perusahaan dapat melakukan penghematan pajak melalui beban penyusutan aset tetap seperti yang telah diketahui besar perolehan nilai aset tetap setelah penilaian kembali.

Adanya selisih lebih revaluasi akibat penilaian kembali atas aset tetap yang dimiliki perusahaan, tentu akan merubah jumlah aset beserta modal pada laporan posisi keuangan perusahaan. Berikut penyajian perubahan laporan posisi keuangan Rumah Sakit Yadika Pondok Bambu.

Gambar 1. Perubahan laporan posisi keuangan atas revaluasi aset tetap

\begin{tabular}{|c|c|c|}
\hline Keterangan & $\begin{array}{l}\text { Sebelum } \\
\text { Revaluasi }\end{array}$ & $\begin{array}{c}\text { Setelah } \\
\text { Revaluasi }\end{array}$ \\
\hline \multicolumn{3}{|l|}{$\begin{array}{l}\text { Aset : } \\
\text { Aset Lancar : }\end{array}$} \\
\hline Kas dan Setara Kas & 1.532.941.979 & 1.275 .103 .825 \\
\hline Piutang Usaha & 13.196.579.565 & 13.196.579.565 \\
\hline Persediaan & 2.754 .855 .884 & 2.754 .855 .884 \\
\hline Pajak Dibayar Dimuka & 598.869 .747 & 598.869 .747 \\
\hline $\begin{array}{l}\text { Jumlah Aset Lancar } \\
\text { Aset Tetap : }\end{array}$ & 18.083.247.175 & 17.825.409.021 \\
\hline Aset Tetap setelah dikurangi Akumulasi Penyusutan & 2.016.016.922 & 4.594.398.461 \\
\hline $\begin{array}{l}\text { Jumlah Aset Tetap } \\
\text { Aset Lain-Lain }\end{array}$ & 2.016 .016 .922 & 4.594.398.461 \\
\hline Jaminan PLN & 76.759 .000 & 76.759 .000 \\
\hline Jumlah Aset Lain-Lain & 76.759 .000 & 76.759 .000 \\
\hline Jumlah Aset & 20.176.023.097 & 22.496 .566 .482 \\
\hline \multicolumn{3}{|l|}{$\begin{array}{l}\text { Kewajiban dan Ekuitas : } \\
\text { Kewajiban Jangka Pendek : }\end{array}$} \\
\hline Hutang Bank & 3.742 .537 .585 & 3.742.537.585 \\
\hline Hutang Usaha & 3.599 .267 .863 & 3.599 .267 .863 \\
\hline Hutang Pajak & 726.253 .266 & 726.253 .266 \\
\hline Biaya Yang Masih Harus di Bayar & 86.809 .744 & 86.809 .744 \\
\hline Jumlah Kewajiban Jangka Pendek & 8.154 .868 .458 & 8.154.868.458 \\
\hline Kewajiban Jangka Panjang : & - & \\
\hline Ekuitas : & & \\
\hline Modal Saham & 6.500 .000 .000 & 6.500 .000 .000 \\
\hline Laba s/d Tahun Lalu & 4.802.936.771 & 4.802.936.771 \\
\hline Laba Tahun Berjalan & 718.217 .868 & 718.217 .868 \\
\hline Selisih Lebih Revaluasi & & 2.320 .543 .385 \\
\hline Jumlah Ekuitas & 12.021 .154 .639 & 14.341.698.024 \\
\hline Jumlah Kewajiban dan Ekuitas & 20.176.023.097 & 22.496.566.482 \\
\hline
\end{tabular}

Sumber : Data Diolah (2020)

Laporan posisi keuangan Rumah Sakit Yadika Pondok Bambu setelah dilakukan
Vol. 7 No. 3 (September - Desember) 2020 penilaian kembali terhadap aset tetap berupa alat dan mesin - mesin, instalasi jaringan listrik, telepon, dan internet, kendaraan, serta peralatan rumah sakit dapat dilihat beberapa perubahan dari laporan posisi keuangan sebelum penilaian kembali.

Berikut penjelasan akun yang mengalami perubahan setelah dilakukan penilaian kembali aset tetap:

1. Kas dan Setara Kas

Perubahan nilai pada akun kas dan setara kas terjadi karena adanya pembayaran $\mathrm{PPh}$ final oleh perusahaan sebesar $10 \%$ dari selisih lebih revaluasi yaitu sebesar Rp 257.838.154, Kas perusahaan yang sebelumnya berjumlah Rp 1.532.941.979, maka setelah dikurangi menjadi Rp1.275.103.825

2. Aset Tetap

Perubahan nilai pada akun aset tetap setelah dikurangi akumulasi penyusutan terjadi karena perusahaan mengalami selisih lebih revaluasi terhadap aset tetap yang dimilikinya sebesar $\mathrm{Rp}$ 2.578.381.539, sehingga diperoleh nilai aset tetap setelah dikurangi akumulasi penyusutan menjadi Rp 4.594.398.461.

3. Selisih Lebih Revaluasi Aset Tetap

Peraturan Menteri Keuangan Nomor 79/PMK.03/2008 pasal 9 ayat 1, mengungkapkan bahwa selisih lebih revaluasi aset tetap perusahaan, dibukukan dalam neraca komersial pada bagian modal atau ekuitas, oleh karena itu pada laporan posisi keuangan terlihat perubahan pada bagian ekuitas yang terdapat tambahan akun berupa selisih lebih revaluasi aset tetap sebesar $\mathrm{Rp}$ 2.320.543.385, perhitungan tersebut diperoleh dari selisih lebih revaluasi sebelum dikurangi PPh final sebesar Rp 2.578.381.539 dikurangi dengan $\mathrm{PPh}$ 
ISSN : $2406-7415$

e-ISSN : 2655 - 9919

JURNAL AKUNTANSI DAN BISNIS KRISNADWIPAYANA

DOI: http://dx.doi.org/10.35137/jabk.v7i3.447

final yang harus dibayar sebesar $\mathrm{Rp}$ 257.838 .154$.

Setelah diketahui total beban yang akan dikeluarkan oleh perusahaan jika melakukan revaluasi terhadap aset tetap, kemudian perusahaan dapat menghitung langsung berapa besar estimasi penghematan pajak yang dapat dilakukan, berikut merupakan tabel perhitungan estimasi penghematan pajak perusahaan:

Tabel 7. Estimasi PenghematanPajak Sumber : Data Diolah (2020)

Tabel 7 menunjukkan hasil dari revaluasi yang dapat dilakukan oleh perusahaan diestimasi masih lebih besar dibandingkan dengan biaya yang harus dikeluarkan akibat adanya penilaian kembali yaitu PPh Final dan Fee jasa penilai. Penghematan pajak yang dapat diperoleh oleh perusahaan atas dilakukannya penilaian kembali adalah sebesar Rp 853.014.196.

\section{KESIMPULAN DAN SARAN}

\section{Kesimpulan}

Berdasarkan analisa dan pembahasan yang telah dilakukan maka dapat ditarik kesimpulan bahwa pengelolaan aset tetap yang dimiliki oleh Rumah Sakit Yadika Pondok Bambu telah dilaksanakan dengan baik namun mendekati akhir masa manfaatnya dan masih dapat berfungsi dengan baik. Selama ini pengukuran akuntansi aset tetap dilakukan dengan metode biaya, sementara akan lebih mencerminkan kewajaran nilai aset tetap apabila pengukuran menggunakan metode
Vol. 7 No. 3 (September - Desember) 2020 revaluasi. Adapun perhitungan perencaanaan pajak terkait pengukuran aset tetap dengan metode revaluasi didapatkan hasil beban pajak menjadi lebih hemat.

\section{Saran}

Terkait dengan kewajaran laporan keuangan dan aset tetap yang dimiliki Rumah Sakit Yadika Pondok Bambu juga mendekati akhir masa manfaatnya maka disarankan Rumah Sakit mempertimbangkan metode revaluasi untuk pengukuran aset tetapnya karena selain

\begin{tabular}{|c|c|}
\hline Keterangan & Jumlah \\
\hline $\begin{array}{l}\text { Penghematan Pajak Setelah } \\
\text { Revaluasi } \\
\text { PPH Final Revaluasi }\end{array}$ & 1.110 .852 .350 \\
\hline ( 10\% X Selisih Lebih Revaluasi ) & 257.838 .154 \\
\hline $\begin{array}{l}\text { Nilai Bersih Penghematan } \\
\text { Pajak }\end{array}$ & 853.014.196 \\
\hline
\end{tabular}

\section{DAFTAR PUSTAKA}

Baridwan, Zaki. (2018). Intermediate Accounting. Yogyakarta: BPFE.

Hery. (2017). Akuntansi, Aset, Liabilitas, dan Ekuitas. Jakarta: PT. Grasindo.

Hery. (2017). Akuntansi Untuk Pemula. Jakarta: Gava Media.

Hery. (2017). Akuntansi Perpajakan. Jakarta: PT. Grasindo.

Ikatan Akuntan Indonesia (IAI). (2014). Standar Akuntansi Keuangan. September 2018, PSAK 16.

Kartikahadi, Hans, et al. (2018). Akuntansi Keuangan Berdasarkan SAK berbasis IFRS. Jakarta: Ikatan Akuntan Indonesia. 
ISSN : $2406-7415$

e-ISSN : $2655-9919$

JURNAL AKUNTANSI DAN BISNIS KRISNADWIPAYANA

DOI: http://dx.doi.org/10.35137/jabk.v7i3.447

Lam, Nelson., dan Lau, Peter. (2015). Akuntansi Keuangan Intermediate Financial Reporting. Jakarta: Salemba Empat.

Ompusunggu, Arles. P. (2017). Cara Legal Siasati Pajak. Jakarta: Mitra Wacana Media.

Rudianto. (2017). Pengantar Akuntansi, Konsep Dan Tehnik Penyusunan Laporan Keuangan. Jakarta: Erlangga.

Suandy, Erly. (2018). Perencanaan Pajak, Vol. 7 No. 3 (September - Desember) 2020

Wijaya, Suparna. (2017). Analisis Revaluasi Aktiva Tetap Pada PT Indonesia Power. Jurnal Pajak Indonesia. Vol.1, No.1, (2017), Hal.106-117. Halaman 2. Undang - Undang Perpajakan Menurut Ketentuan Perpajakan (pasal 11 Undang - Undang PPh No.36 tahun 2008).

Waluyo. (2018). Akuntansi Perpajakan. Jakarta: Salemba Empat 